\title{
INTERNATIONAL LAW: WAIVER OF SOVEREIGN IMMUNITY
}

M ucr doubt has been cast on the value of a sovereign's waiver of
immunity by the recent holding of Rich $v$. Naviera Vacuba that a sovereign may repudiate such a waiver at any time prior to submission to suit or execution.

The case arose when the captain and crew of the Cuban vessel Bahia De Nipe, diverting their ship from its destination in the Soviet Union, brought it within the territorial waters of the United States to seek political asylum. Libels were filed against the ship and its cargo in the District Court for the Eastern District of Virginia." One of the claimants, Mayan Lines, ${ }^{3}$ had previously sued Cuba in a Louisiana

${ }^{1} 197$ F. Supp. 710 (E.D. Va.) (Hoffman, J.), aff'd, 295 F.2d 24 (4th Cir. 1961).

${ }^{2}$ Five libels were filed: One on behalf of judgment creditors from personal injury claims against the company which owned the Balia De Nipe prior to its nationalization, one by a creditor of the former owner, one by the United Fruit Sugar Company against the cargo alone, one on behalf of the defecting crew members for wages, and one by the Mayan Lines, S.A.

A principal point of contention in the case concerned the fact that the Coast Guard, acting under executive orders, physically prevented a United States Marshal from effecting an attachment of the Bahia De Nipe. The district court and the Court of Appeals held that the Coast Guard had acted without legal authority. Rich v. Naviera Vacuba, 197 F. Supp. 710, 711-18, 295 F.2d 24, 25 (1961).

${ }^{3}$ This note deals almost exclusively with the claim of the Mayan Lines since it was the only libellant possessing a waiver of immunity. Another aspect of the case significant in another area of the law of sovereign immunity is that concerned with the libel filed by the United Fruit Sugar Company against the cargo of sugar on board the Bahia De Nipe. The Company claimed that the sugar had been wrongfully taken from it in connection with the nationalization of the Company's sugar plantations in Cuba. The United States Government maintained that while the consfiscation was unlawful under international law, this "does not mean that Cuba, as between itself and petitioner, does not have valid title to the expropriated property so far as our courts are concerned. ..." Memorandum of the United States in Opposition to the Application for a Stay, filed September 11, 1961, with the Supreme Court. Quoted from Reply Brief of Appellant, p. 6, Banco Nacional de Cuba v. Sabbatino, Second Circuit Court of Appeals, December 28, 196x.

The district court rejected the Company's argument on the ground that "vessels and cargo expropriated by, and in the possession of, a foreign sovereign are immune from suit upon a suggestion of immunity." Rich v. Naviera Vacuba, 197 F. Supp. at 724. - But see, Stephen v. Zivnostenska Banka, 15 App. Div. $2 d 111,222$ N.Y.S.2d 128 (196r). The Court of Appeals referred to but did not specifically discuss the claims made by the Company. Mr. Chief Justice Warren denied the United Fruit Company's petition for a stay, citing the cases of Underhill v. Hernandez, $x 68$ U.S. 250, 252 (1897), and Ricaud v. American Metal Co., 246 U.S. 304, 309 (1918). 
state court on a claim arising out of a commercial transaction. The attorney for Cuba had assented to a court-approved settlement whereby the attorney purported to exercise on behalf of Cuba an absolute waiver of immunity as to execution and enforcement of the judgment. ${ }^{4}$ In the instant case, the Mayan Lines sought to enforce the prior judgment. On application of the Republic of Cuba, the United States Department of State filed, for reasons of foreign policy, a suggestion of immunity ${ }^{5}$ with the district court. ${ }^{6}$ The court, treating the original waiver as valid, ${ }^{7}$ held that the present assertion of immunity was effective to

The expropriations aspect of the Bahia De Nipe case is discussed in Baade, The Validity of Foreign Confiscations: An Addendum, 56 AM. J. INT'L L. 504 (1962); Rabinowitz, Immunity of State-Owned Ships and Barratry, J. Bus. L., Jau. 1962, p. 89; Reply Brief of Appellant, Banco Nacional de Cuba v. Sabbatino, pp. 3-9, Second Circuit Court of Appeals, filed on December 28, 1961.

'The settlement included a submission to the court's jurisdiction, a compromise of the original $\$ 1,000,000$ claim for $\$ 500,000$, and an absolute waiver of immunity. Portions of the latter read as follows: "Cuba waives any and all rights of sovereign immunity which it may now or hereafter be entitled to plead. Republic of Cuba acknowledges, admits and declares that the judgment herein provided for shall be a valid, legal and binding judgment. . . . With respect to the enforcement and execution of said judgment, Republic of Cuba hereby specially and specifically waives the provisions, exemptions or immunities which it may be entitled to plead as a bar in the enforcement and execution of this judgment. ..." See $197 \mathrm{~F}$. Supp. at 719-720.

"The assertion of immunity was made on behalf of the Republic of Cuba through the auspices of the Government of Switzerland, which presently handles the diplomatic relations between the United States and Cuba.

It should be noted that there never was a specific repudiation of the waiver. The Swiss government merely made a general assertion of immunity as to the Bahia De Nipe which did not mention the waiver. Rich v. Naviera Vacuba, 197 F. Supp. 7 Io, 720-21 (1961).

The following circumstances explain the great interest of the U.S. Government in the Bahia De Nipe case. The entire controversy took place in the context of the hijacking of planes and boats between the U.S. and Cuba. On July 25,1961 , an Eastern Airlines plane was hijacked and landed in Cuba. The United States on August 2, 196r, made a solemn declaration before the United Nations that it would return all hijacked property. On August 16, 196r, (the day before the Bahia De Nipe arrived at Norfolk), Cuba returned the hijacked Eastern airliner. President Kennedy, himself intervened in the Bakia De Nipe case when on September I I he "advised the Solicitor General that, in the light of the time already expired, it is urgent that this Cuban vessel be released immediately without further delay." Memorandum for the United States in Opposition to Application for Stay by libellant Rich, p. 12, Files of Supreme Court. Quoted in Reply Brief for Appellant, p. 9, Banco Nacional de Cuba v. Sabbatino, Second Circuit Court of Appeals, December 28, I96r.

${ }^{\circ}$ There was some question whether the court could entertain a suggestion of immunity until the ship was attached, but the court relied on The Carlo Poma, 259 Fed. 369 (2d Cir. 1919), wacated on jurisdictional grounds, 255 U.S. 219 (1920), to hold that it could. Rich v. Naviera Vacuba, 197 F. Supp. at 718-19 (I96I).

${ }^{7}$ The United States Government argued that the waiver was not valid because 
reinstate Cuba's immunity notwithstanding the waiver's incorporation in a court-approved settlement. The Court of Appeals for the Fourth Circuit affirmed per curiam. ${ }^{8}$

The district court felt precluded by the Swedish State Railway case ${ }^{0}$ from giving effect to the waiver. That case, however, dealt with a judgment entered against the Swedish State Railway in a suit in which the Swedish Government had made no plea of sovereign immunity. The plea was first entered in the action to collect the judgment. The court dismissed the action on the ground that a sovereign's submission to suit was not a waiver of immunity from execution. Thus, the district court would seem to be mistaken in considering the Swedish State Railway case authority for the proposition that a waiver, once made, may be subsequently retracted.

A sounder precedent for the court's decision is the case of Principality of Monaco v. Mississippi, ${ }^{10}$ which was cited as establishing a

there had been no official act by the sovereign and because there was no evidence in the court record of the attorney's authority to execute the waiver. In rejecting this argument, the court found as a fact that the attorney had full and complete authority to execute the waiver and held that no official act of the sovereign except the acts of its attorney are necessary. The court relied upon The Sao Vicente, 295 Fed. 829 (3rd Cir. $\times 924$ ), in which it was held that a general appearance entered by the attorney for the Republic of Portugal constituted a valid waiver of immunity from suit even though Portugal later objected to the attorney's action. In the Bahia $D e$ Nipe case there was no indication whether Cuba considered the waiver to have been validly executed. Compare United States of Mexico v. Rask, 118 Cal. App. 21, 4 P.2d 98x (1931) (a claim of sovereign immunity cannot be made by a private attorney).

The British rule seems to be contra. See Baccus S.R.L. v. Servicio Nacional, [x957] 1 Q.B. 438; Wedderburn, Sovereign Immunity of Foreign Public Corporations, 6 INT'L \& CoMP. L.Q. 290 ( (957); Note, 73 L.Q. REv. 286 (1957).

${ }^{8}$ It is perhaps significant to note the speed at which the events in the Bahia de Nipe case progressed. The first libel was filed on August $18, \times 961$, the decision of the district court was announced on August 29, 1961, the Court of Appeals handed down its opinion on September 7, 1961, the Chief Justice denied stays on September 11-14, 1961, and the Bahia De Nipe sailed from the United States on September 15, 1961.

- The Swedish State Railway case [Dexter \& Carpenter v. Jarnvagsstyrelsen, 43 F.2d 205 (2d Cir. 1930)] "appears to foreclose the right of Mayan Lines, S.A., to prevail in its efforts to effectively attach the Bahia De Nipe." 197 F. Supp. at 722.

For discussion of the Swedish Railway case see 25 AM. J. INT' ${ }^{3}$ L. 335 (1931); Note, 3r Colum. L. REv. 660 (1931); Note, 16 ST. Lours L. REv. 177 (1931); Note, 79 U. PA. L. REv. 644 (1931).

${ }^{20} 292$ U.S. 313 (1934). The case involved a suit brought upon bonds issued by the defendant. The Court dismissed the suit on the ground that a state may not be sued by a foreign government without its consent. In the course of the opinion, the Court commented: "The contracts between a nation and individuals are only binding on the conscience of the sovereign, and have no pretention to a compulsive force. They confer no right of action independent of the sovereign will." 292 U.S. at 325 . See 
general doctrine that a sovereign's contract is binding only on its conscience. The district court considered the waiver in favor of the Mayan Lines as only a "contractural agreement not to plead immunity"11 even though the waiver was incorporated in a valid judgment. Consequently, the waiver was viewed as binding only on the conscience of the Republic of Cuba, subject to repudiation at will. ${ }^{12}$

Although the district court opinion did not so state, its decision that a sovereign may repudiate a contractual waiver was in conformity with the British rule. In the leading British case, Duff Development Co. v. Government of Kelantan, ${ }^{13}$ a contract between plaintiff and the sovereign defendant provided for arbitration of any dispute arising under the contract. Both parties further consented to judicial enforcement of the arbitral award. A dispute later submitted to arbitration resulted in an award in favor of the plaintiff. When the plaintiff sought enforcement of the award, the sovereign pleaded its immunity as a defense to the court's purported authority. The House of Lords held that since there had been no submission to the court, the repudiation of the agreement to submit, while a breach of the contract with the plaintiff, nevertheless precluded the court from taking jurisdiction. ${ }^{1 *}$

Lamont v. Travelers Ins. Co., 28I N.Y. 362, 24 N.E.2d 8I (1939). The district court in the instant case also cited Lynch v. United States, 292 U.S. 57 I (1934), which quoted with approval the above passage from the Mississippi case.

${ }^{12} 197$ F. Supp. at 723.

${ }^{22}$ The district court held that the Louisiana judgment incorporating the waiver was entitled to full faith and credit. Id. at 722 . It might be argued, therefore, that the waiver should be given greater effect than a simple contractural waiver. Indeed, no case cited by the court nor any of the leading British cases involved a waiver included in a court judgment.

${ }^{10}$ [1924] A.C. 797. For discussions of the case and the problems it raises, see Cohn, Waiver of Immunity, 34 BRIT. YB. INT'L L. 260 (1958); Schmitthoff, The Claim of Sovereign Immunity in the Law of International Trade, 7 INT'L \& COMP. L.Q. 452, 462 (1958); Note, 36 HARv. L. REv. 623 (I923); Note, 4I L.Q. Rev. I (I925).

${ }^{14}$ The district court's holding finds strong support in Viscount Cave's statement in the Duff case that "if therefore a sovereign having agreed to submit to jurisdiction refuses to do so when the question arises, he indeed may be guilty of a breach of his agreement but he does not thereby give actual jurisdiction to the court." [ig24] A.C. 797, S09. See Mighell v. Sultan of Johore, [1894] I Q.B. 149.

For a more recent application of the British rule, see Kahan v. Pakistan Federation, [1951] $2 \mathrm{~K} . \mathrm{B}, 1003$, in which the court held that in spite of a sovereign's contractual agreement to submit to jurisdiction, dismissal was required since the sovereign had made no submission directly to the court. It is significant to note that the judges declined to adopt the restrictive doctrine of sovereign immunity that was urged by the plaintiff. See footnote 15 infra and accompanying text.

See also, United States v. Republic of China, [1950] Q.W.N. 6, [1950] Int'l L. Rep. 
This rule, apart from considerations of its fairness, is consistent with British acceptance of the absolute theory of sovereign immunity which confers immunity upon a sovereign in its non-governmental as well as governmental functions. ${ }^{15}$ However, the district court's adoption of the British rule would seem inconsistent with the United States' recognition, in the Tate Letter, ${ }^{16}$ of the restrictive theory of sovereign immunity which seeks to prevent sovereigns from asserting governmental prerogatives when dealing with private parties in nongovernmental activities. Indeed, the claimants in the Bahia De Nipe case argued that the State Department's suggestion of immunity conflicted with its earlier acceptance of the restrictive theory. ${ }^{17}$ It would seem, that unlike the court's holding that a sovereign may repudiate a contractual waiver, the State Department's suggestion that the Bahia De Nipe be free from attachment is not inconsistent with the restrictive theory, since that theory has not been extended to allow attachment of a sovereign's property for purposes of execution. ${ }^{18}$

168, in which the Supreme Court of Queensland held that a sovereign's right to immunity is unhampered by any contractual waiver it may have made.

${ }^{25}$ The case generally cited as establishing the British acceptance of the absolute theory and the rejection of the restrictive theory is The Parlement Belge, 5 P.D. 197 (1880). See Kahan v. Pakistan Federation, supra note 14.

${ }^{10}$ Letter of the Acting Legal Adviser of the State Department [Jack B. Tate] to the U.S. Attorney General Concerning Sovereign Immunity of Foreign Governments, 26 Dep'T STate Bull. 984 (1952). The Tate Letter summarizes the restrictive theory: "the immunity of the sovereign is recognized with regard to sovereign or public acts (jure imperii) of a state, but not with respect to private acts (jure gestionis)." One of the primary policy considerations stated in the letter is that "the Department feels that the widespread and increasing practice on the part of governments of engaging in commercial activities makes necessary a practice which will enable persons doing business with them to have their rights determined in the courts."

For a judicial discussion and application of the Tate Letter, see National City Bank of New York v. Republic of China, 348 U.S. 356 (1955). The Supreme Court refuced to recognize the assertion of sovereign immunity as to a counterclaim based on the sovereign's defaulted notes. The district court in the Bahia De Nipe case refused to apply the doctrine of the National City Bank case that fair play must be taken into account in the application of sovereign immunity. Rich v. Naviera Vacuba, 197 F. Supp. at 723 .

${ }^{17}$ In rejecting this contention, the district court stated that "no policy with respact to international relations is so fixed that it cannot be varied in the wisdom of the Executive." I 97 F. Supp. at 724 .

${ }^{18}$ The active role which the State Department took in urging that the contractual waiver not be honored rather than just a general immunity from attachment would seem to be inconsistent with the policy of the Tate Letter.

Originally, the State Department did not interpret the restrictive doctrine as allowing the attachment of a sovereign's property even for the limited purpose of obtaining jurisdiction. New York and Cuba Mail Steamship Co. v. Republic of Korea, 132 F. Supp. 
The State Department, however, did not stop with a mere suggestion of immunity from attachment in the instant case. The department maintained and received the district court's approval of the proposition that it is not bound by the Tate Letter and may change its policy at will. ${ }^{10}$ The language and tenor of the district court's holding, added to the State Department's contentions, leave in serious doubt whether the United States may now be said to follow the restrictive or absolute theory of sovereign immunity.

The Fourth Circuit affirmed the district court in a per curiam opinion on the ground that $E_{x}$ Parte $P_{e r i^{20}}$ makes a suggestion of im-

684 (S.D.N.Y. 1955). The State Department seems to have now changed this policy and to allow attachment in order to obtain jurisdiction. Stephen v. Zivnostenska Banka, 222 N.Y.S.2d 128, 134 (1961).

For arguments concerning the extension of the restrictive theory to allow attachment and execution, see Bishop, New United States Policy Limiting Sovereign Immunity, 47 AM. J. INT'L I. 93 (1953); Claudy, The Tate Letter and the National City Bank Case: Implication, 1958 AM. Soc. OF INT'L LAW, Proceedincs 80; Delson, Applicability of Restrictive Theory of Sovereign Immunity to Actions to Perfect Attach ment, 1961 AM. Soc. of INT'L LAW, ProceEdings 121 ; Drachsler, Some Observations on the Current Status of the Tate Letter, 54 AM. J. INT'L L. 790 (1960); Reeves, Comments, $196 \mathrm{I}$ AM. Soc. OF INT'L LAW, Procendings 130; Timberg, Sovereign Immunity, State Trading, Socialism and Self-Deception, 56 Nw. U.L. REv. 109 (I96I).

10 "But it [the Tate Letter] is wholly and solely a guide to the State Department's own policy, not the declaration of a rule of law or even of an unalterable policy position; and, in addition, it sets forth only some of the governing considerations and does not purport to be all-inclusive or exclusive." Memorandum of the United States in Opposition to the Application for a Stay, filed September II, I96I, with the Supreme Court. Quoted in J. Bus. L., Jan. 1962, p. 54 .

${ }^{20} 318$ U.S. $57^{8}$ ( 1942 ). In this case, the district court acquired jurisdiction by attachment of a ship which allegedly belonged to the Republic of Peru. The Supreme Court held that in view of the State Department suggestion of immunity the suit must be dismissed. The Court specifically left open the point decided by the district court in Bahia De Nipe when it said: "We have no occasion to decide whether the court should surrender the vessel and dismiss the suit on certification of sovereign immunity by the Secretary, made after the friendly sovereign has once unqualifiedly assented to a judicial determination of the controversy." 318 U.S. at 590.

Mr. Chief Justice Warren also cited the Peru case in denying petitions for a stay in the instant case. In addition, the Chief Justice also cited Republic of Mexico v. Hoffman, 324 U.S. 30 (1945), in which the Court honored a suggestion of immunity as to a vessel owned but not possessed by Mexico. The Court stated the effect to be given a State Department suggestion as follows: " $\mathrm{It}$ is therefore not for the courts to deny an immunity which our government has seen fit to allow, or to allow an immunity on new grounds which the government has not seen fit to recognize." 324 U.S. 30, 35 (I945).

For a criticism of the courts' uncritical acceptance of State Department suggestions, see Franck, The Courts, The State Department and National Policy: A Criterion for Judicial Abdication, 44 MrNN. L. REv. I IOI (1960). 
munity by the State Department binding on the court. Although not referring to the district court's holding that a sovereign may repudiate a valid waiver of immunity, the Court of Appeals did mention the waiver possessed by the Mayan Lines, but only briefly commented that in the absence of State Department action the effect to be given the waiver would be "a suitable subject for inquiry."

The Fourth Circuit's holding can be supported on the policy of allowing the executive department all possible control over foreign affairs-a policy especially appealing in the politically-charged Bahia De Nipe case. However, the broader holding of the district court that a waiver may be repudiated even in the absence of a State Department suggestion of immunity is seemingly without policy support. If the district court is followed, any provisions in contracts between private parties and a sovereign whereby the sovereign purports to waive its immunity to suit or execution will no doubt be rendered valueless, ${ }^{22}$ while the strict import of the Court of Appeals' opinion will be to make such contracts useless only when the State Department suggests immunity. The partial limitation of the effectiveness of waivers imposed by the Swedish State Railway case ${ }^{23}$ is supportable on the ground of protecting the sovereign from indiscriminate execution. If a sovereign were subject to execution every time it consented to suit, its governmental functions might seriously be interfered with by those obtaining execution on consulates and other vital property. However, the need for such protection ceases when, as in Bahia De Nipe, a sovereign voluntarily executes a waiver of immunity. In such a case, the sovereign can incorporate in the waiver any exemptions it deems necessary or desirable. Thus, the district court's holding deprives private parties of much-needed protection, only to grant the sovereign unnecessary power.

\footnotetext{
${ }^{21}$ Rich v. Naviera Vacuba, 295 F.2d 24, 26 (4th Cir. 1961).

${ }^{22}$ Query also the effect on the waiver of sovereign immunity required by the Civil Aeronautics Board when issuing permits to foreign air carriers. 14 C.F.R. $\$ 339.22$ (b).

${ }^{38}$ Dexter \& Carpenter v. Jarnvagsstyrelsen, 43 F.2d 705 (2d Cir. x930) (a waiver .of immunity from suit does not carry with it a waiver of immunity from execution).
} 